\title{
DEOXYRIBONUCLEIC ACID SYNTHESIS IN VITRO IN NORMAL AND DELAYED NIDATION PREIMPLANTATION BLASTOCYSTS OF ADULT RATS
}

\author{
MRINAL K. SANYAL* AND R. K. MEYER \\ Department of Zoology, University of Wisconsin, \\ Madison, Wisconsin 53706, U.S.A.
}

(Received 14th December 1971, accepted 25th Fanuary 1972)

\begin{abstract}
Summary. Blastocysts recovered from adult cycling rats on Day 5 of pregnancy had thirty-four nuclei as determined by the squash technique. The nuclei actively incorporated $\left[{ }^{3} \mathrm{H}\right]$ thymidine in vitro when examined by autoradiography. In delayed-nidation blastocysts on Day 9 of pregnancy, the number of nuclei observed was seventy-four, and a smaller number of nuclei incorporated $\left[{ }^{3} \mathrm{H}\right]$ thymidine than on Day 5 under identical experimental conditions. Oestrogen and progesterone treatment $30 \mathrm{hr}$ before autopsy of rats with delayed nidation caused stimulation of DNA synthesis in the nuclei of blastocysts before implantation. This was indicated by a greater number of nuclei incorporating $\left[{ }^{3} \mathrm{H}\right]$ thymidine than in the controls which did not receive oestrogen.
\end{abstract}

Embryonic differentiation in mammals beyond the blastocyst stage occurs after implantation of the blastocyst into the uterus. Artificially, implantation can be delayed indefinitely in the rat by ovariectomy on Day 3 of pregnancy followed by progesterone treatment. Implantation can be initiated in these rats by the injection of oestrogen with progesterone (Cochrane \& Meyer, 1957; Nutting \& Meyer, 1963, 1964). During delayed nidation, the blastocysts are relatively 'dormant' and are free in the uterine lumen (Baevsky, 1963). The present study deals with the growth of and DNA synthesis in the blastocysts of control adult rats and those with experimentally induced delayed nidation. Growth of the blastocyst was estimated by counting the number of nuclei and DNA synthetic activity was assessed by the incorporation of $\left[{ }^{3} \mathrm{H}\right]$ thymidine into the nuclei. The stimulatory influence of oestrogen on DNA synthesis in the nuclei of blastocysts before their implantation was noted.

Mature female rats (Holtzman Co.), 85 to 90 days old and weighing 220 to $240 \mathrm{~g}$, were housed under normal laboratory conditions of daily illumination (14 hr light/10 hr darkness) and temperature of 26 to $27^{\circ} \mathrm{C}$. Pro-oestrous rats were placed with experienced breeder males overnight and mating was ascer-

* Present address: Laboratory of Human Reproduction and Reproductive Biology, and Department of Surgery (Division of Gynecology), Peter Bent Brigham Hospital, and Department of Obstetrics and Gynecology, Harvard Medical School, 45 Shattuck Street, Boston, Massachusetts 02115. 
tained the next morning by the presence of spermatozoa in the vaginal smear or a vaginal plug (Day 1 of pregnancy). Blastocysts were obtained from the following experimental groups: (a) control rats on Day 5 of pregnancy, (b) rats on the 9th Day of pregnancy in which delayed nidation was induced by bilateral ovariectomy on Day 3 and the injection of a daily dose of $4.0 \mathrm{mg}$ progesterone in $0.1 \mathrm{ml}$ corn oil (Cochrane \& Meyer, 1957), and (c) rats which received the same treatment as those in Group b, together with an injection of $1 \mu \mathrm{g}$ oestrone in $0.1 \mathrm{ml}$ corn oil $30 \mathrm{hr}$ before autopsy. The rats were killed by an overdose of ether and the uteri were dissected out and wiped with moist filter paper. The blastocysts were recovered by flushing the uteri with $500 \mu \mathrm{l}$ Medium 199 (Microbiological Associates Inc.; containing sodium bicarbonate, $\mathrm{pH}$ 7.2).

The blastocysts from each rat were washed and incubated in $50 \mu \mathrm{l}$ Medium 199 with $10 \mu \mathrm{Ci}$ thymidine-methyl $-{ }^{3} \mathrm{H}$ (Nuclear Chicago; specific activity $18 \mathrm{Ci} / \mathrm{mm}) / \mathrm{ml}$ in an atmosphere of $95 \%$ air and $5 \%$ carbon dioxide in a desiccator saturated with water vapour at $38^{\circ} \mathrm{G}$ for $1 \mathrm{hr}$ (15.00 to 16.00 hours). The blastocysts were washed after incubation with $500 \mu l$ fresh Medium 199, and flattened on a gelatinized slide with $1 \%$ acetic acid. The preparations were then subjected to autoradiography to count the number of nuclei incorporating tritiated thymidine. The nuclei utilize exogenous precursor for DNA synthesis and $\left[{ }^{3} \mathrm{H}\right]$ thymidine is primarily incorporated into DNA (Sanyal \& Meyer, $1969,1970)$. The standard error within a treatment group was calculated on the average of the total number of nuclei and $\left[{ }^{3} \mathrm{H}\right]$ thymidine-labelled nuclei per recovered blastocyst after processing for each rat. The data were statistically evaluated by Duncan's multiple range test (Steel \& Torrie, 1960) and computed in Fortran, using CDC 1604.

On Day 5 of pregnancy, after processing for autoradiography, forty-four blastocysts were recovered from ten control rats (Table 1). The average number of nuclei per blastocyst was $33 \cdot 83 \pm 1 \cdot 57$, and $63 \cdot 19 \pm 2 \cdot 83 \%$ of these nuclei incorporated $\left[{ }^{3} \mathrm{H}\right]$ thymidine. Statistical analysis indicated that the average number of nuclei and nuclei incorporating $\left[{ }^{3} \mathrm{H}\right]$ thymidine in the blastocysts without zonae pellucidae were not significantly different from those with zonae. In the present study, the loss of zonae was not correlated directly with the growth of the embryo on Day 5 of pregnancy in terms of number of nuclei. These results agree with our observations on the blastocysts of gonadotrophinstimulated immature rats (Sanyal \& Meyer, 1969). Yasukawa \& Meyer (1966) observed that the loss of zonae before implantation in the adult rat was random and was facilitated by the action of progesterone and oestrogen.

The number of nuclei in the blastocysts from adult rats on Day 9 of pregnacy was observed to have increased to $73 \cdot 64 \pm 8 \cdot 60$, and $3 \cdot 80 \pm 1 \cdot 27 \%$ of the nuclei incorporated $\left[{ }^{3} \mathrm{H}\right]$ thymidine after $1 \mathrm{hr}$ of incubation. The extent of incorporation, assessed visually by the number of grains over the nuclei, was also very low in the delayed implantation blastocysts.

It was observed earlier that blastocysts free in the uterine lumen assume an elliptical shape $12 \mathrm{hr}$ after treatment with oestrone to delayed-implantation adult rats. The elliptical appearance is maintained for $30 \mathrm{hr}$ after treatment, and by $36 \mathrm{hr}$, the trophoblast of the blastocyst invades the maternal endometrium (Yasukawa \& Meyer, 1966). In our study, treatment of adult rats with 


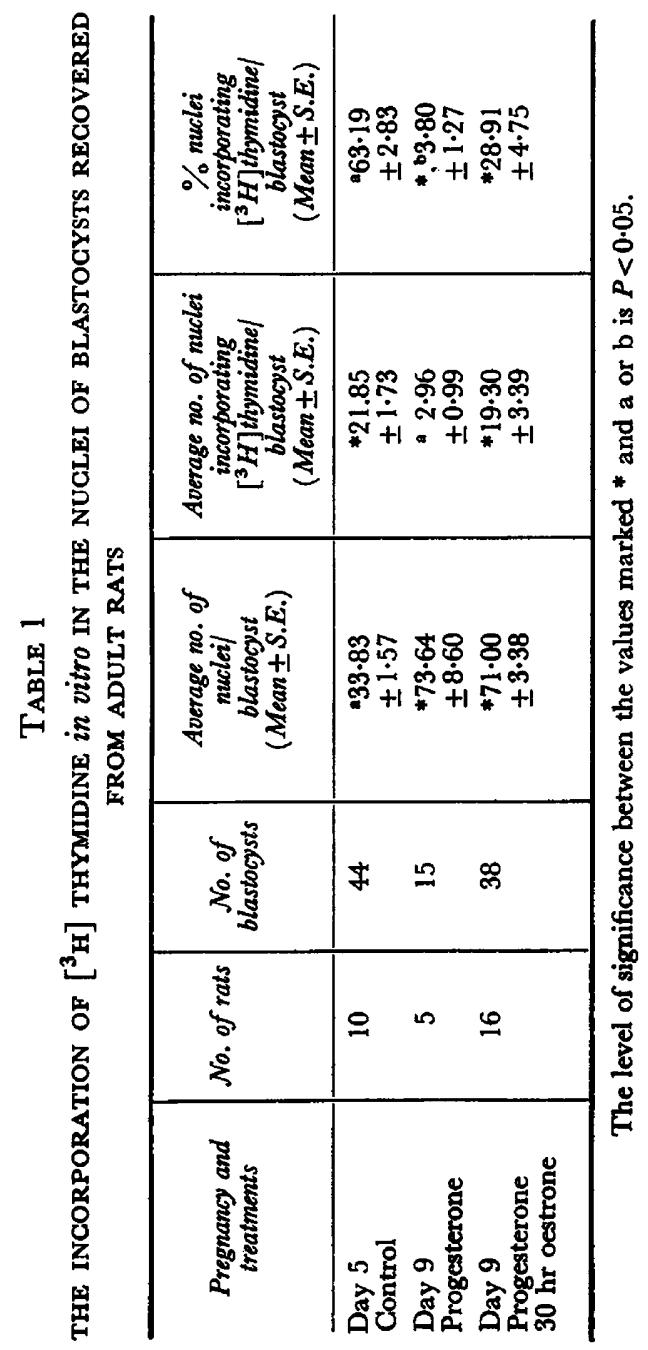


oestrone $30 \mathrm{hr}$ before autopsy remarkably influenced the DNA synthesis in the blastocyst and resulted in a significant rise in the number of cell nuclei incorporating $\left[{ }^{3} \mathrm{H}\right]$ thymidine $(28.91 \pm 4 \cdot 75)$. This increased value was approximately seven to eight times the number in the blastocysts from rats without oestrone treatment.

In previous studies on DNA synthesis in superovulated blastocysts from immature rats, we postulated that during delayed nidation a large number of nuclei in the blastocyst are arrested in either the $G_{1}$, the $G_{2}$ or both phases of the cell cycle. The injection of oestrogen with progesterone, directly or indirectly stimulated the $\mathrm{G}_{1}$ nuclei to advance to the S-phase (Sanyal \& Meyer, 1970). The synthesis of RNA and protein is also markedly stimulated by oestrogen treatment in the blastocysts under similar conditions (Prasad, Dass \& Mohla, 1968; Dass, Mohla \& Prasad, 1969; Jacobson, Sanyal \& Meyer, 1970; Mohla, Prasad \& Dass, 1970).

In the present study, there was no increase in the number of nuclei after oestrone treatment. However, $25 \%$ more nuclei incorporated $\left[{ }^{3} \mathrm{H}\right]$ thymidine compared to controls exposed to progesterone alone. It is assumed that at least $25 \%$, possibly more, nuclei were in $\mathrm{G}_{1}$ during delayed nidation. If the implantation and trophoblast invasion is initiated $36 \mathrm{hr}$ after oestrogen treatment (Yasukawa \& Meyer, 1966), the physiological state of the blastocyst $6 \mathrm{hr}$ before implantation was represented in our experiments. The present study demonstrates that oestrogen in conjunction with progesterone markedly influences the DNA metabolism of the blastocyst from adult rats before implantation.

\section{REFERENCES}

BAEvSKy, U. B. (1963) Effect of embryonic diapause on the nuclei and mitotic activity of mink and rat blastocyst. In: Delayed Implantation, p. 141. Ed. A. C. Enders. University of Chicago Press.

Cochrane, R. L. \& Meyer, R. K. (1957) Delayed nidation in the rat induced by progesterone. Proc. Soc. exp. Biol. Med. 96, 155.

Dass, C. M. S., Mohla, S. \& Prasad, M. R. N. (1969) Time sequence of action of estrogen on nucleic acid and protein synthesis in the uterus and blastocyst during delayed implantation in the rat. Endocrinology, 85, 528.

Jacobson, M. A., Sanyal, M. K. \& Meyer, R. K. (1970) Effect of estrone on RNA synthesis in preimplantation blastocysts of gonadotrophin-treated immature rats. Endocrinology, 87, 383.

Mohla, S., Prasad, M. R. N. \& Dass, C. M. S. (1970) Nucleic acid and protein synthesis in the blastocyst and uterus during early pregnancy in the rat. Endocrinology, 86, 982.

Nutting, E. F. \& Meyer, R. K. (1963) Implantation delay, nidation, and embryonal survival in rats treated with ovarian hormones. In: Delayed Implantation, p. 233. Ed. A. C. Enders. University of Chicago Press.

Nutring, E. F. \& Meyer, R. K. (1964) Effect of oestrone on the delay of nidation, implantation and foetal survival in ovariectomized rats. J. Endocr. 29, 235.

Prasad, M. R. N., Dass, C. M. S. \& Mohla, S. (1968) Action of oestrogen on the blastocyst and uterus in delayed implantation-an autoradiographic study. F. Reprod. Fert. 16, 97.

SANYAL, M. K. \& MEYeR, R. K. (1969) Deoxyribonucleic acid synthesis in vitro in preimplantation blastocysts of prepuberal rats ovulated with gonadotrophins. Endocrinology, 85, 585.

SANYAL, M. K. \& MEYeR, R. K. (1970) Effect of estrone on DNA synthesis of preimplantation blastocysts of gonadotrophin-treated immature rats. Endocrinology, 86, 976.

Steel, R. G. D. \& Torre, J. H. (1960) Principles and procedures of statistics, p. 107. McGraw-Hill, New York.

YasuKaWA, J. J. \& MEYER, R. K. (1966) Effect of progesterone and oestrone on the pre-implantation and implantation stages of embryo development. F. Reprod. Fert. 11, 245. 